In the melting pot of modern science, chemistry's cutting edge is being rebranded as biology or nanotechnology. David Adam wonders if false modesty is leaving chemists to pick up the crumbs from their own periodic table.

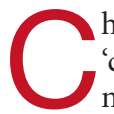

hemistry likes to style itself as the 'central science', but perhaps 'bridesmaid science' would be more appropriate. While other scientific disciplines reap maximum publicity from their triumphs, chemists have seen some of their brightest moments claimed by rival fields. From the discovery of lifesaving drugs to the explosion of work on carbon nanotubes, new developments in chemistry often seem to end up being appropriated by other disciplines.

For researchers fighting to get the subject the recognition they say it deserves, chemistry simply does not smell as sweet by another name. And as chemistry's borders become blurred by collaborations with physicists and biologists, the researchers argue that it is time for the subject to claim achievements as its own - or risk failing to attract the brightest young scientists.

George Whitesides, a chemist at Harvard University, agrees that the most interesting parts of chemistry often end up being called something else. "It's something that I've never quite understood about chemists," he says. "They are in some profound way fairly modest. They develop these interesting techniques and then somebody else takes them and runs with them and nobody screams and hollers. You won't find a biologist who'll put up with someone taking what they're doing and walking off with it."

\section{Unsung heroes}

Whitesides' lab would be a good place to start the campaign to reverse this trend. $\mathrm{He}$ uses traditional chemistry techniques to investigate everything from how bacteria colonize surfaces to the design of fuel cells. One of the main current interests of his group is the synthesis of artificial cell membranes in the lab. Researchers can use these synthetic membranes to study how enzymes and sugars are adsorbed and recognized at the surface of living cells.

"If you think of what has happened in biology, a lot of it depends hugely on chemistry," says Whitesides. Early work on DNA, he points out, was done by chemists. "You wouldn't have DNA without the synthetic procedures for making nucleic acids and the gels to separate and run things out. Now that
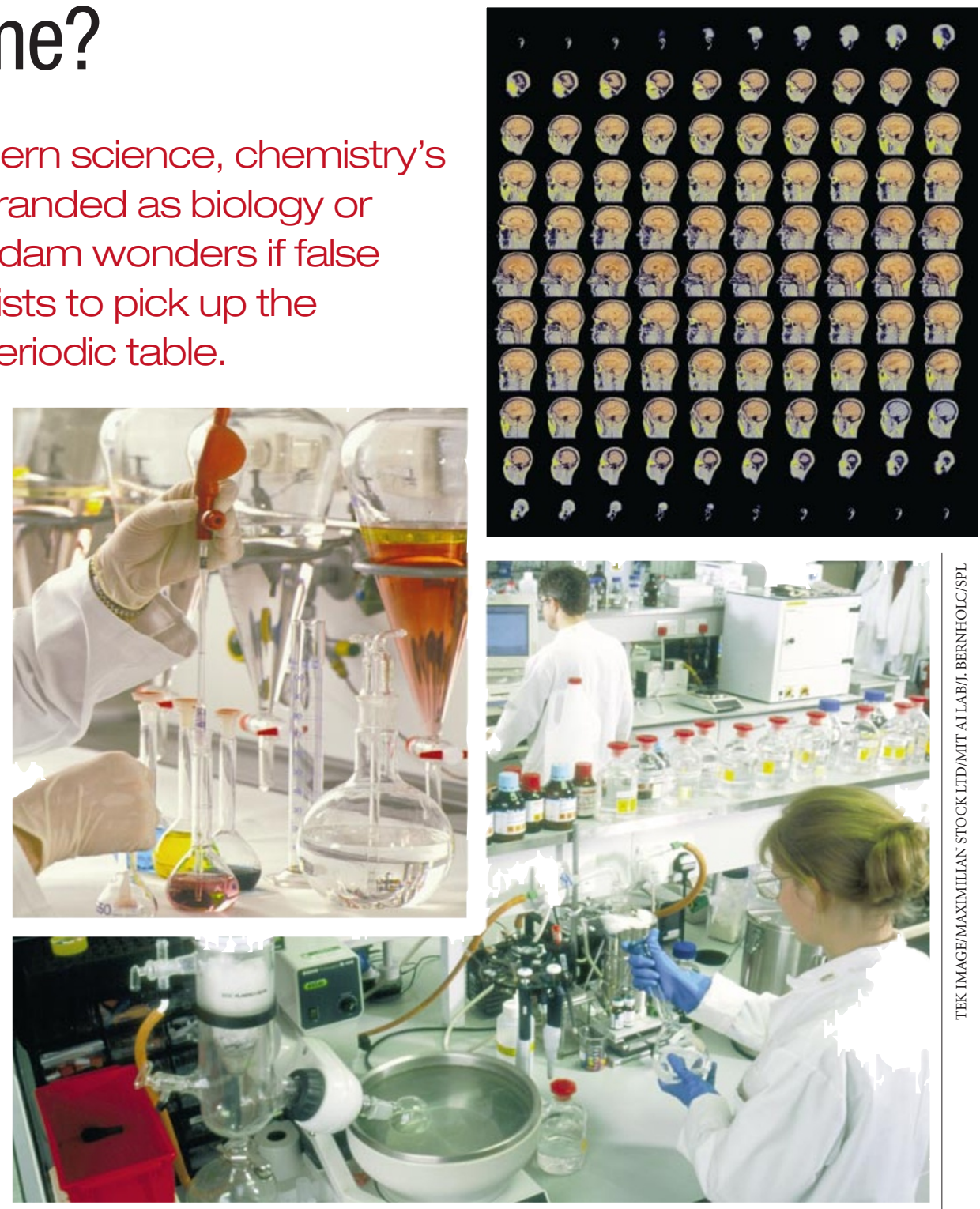

Passing the buck: chemists discovered the existence of buckyballs (top right) as well as playing a vital role in the development of MRI scans (top left) — but other disciplines are now making the running.

ends up being called biology.”

Chemists also played a vital role in developing nuclear magnetic resonance spectroscopy and its medical spin-off, magnetic resonance imaging (MRI). But today, MRI is often seen as an example of how physics can contribute to biomedical research.

Like the supporters of an impoverished lower-league soccer club, chemists have grown used to seeing their star performers transferred to more glamorous teams. Even Nobel prizewinning chemistry, it seems, does not stay chemistry for long. The discovery of the carbon spheres known as buckyballs was awarded the chemistry Nobel in 1996, but much of the work that has stemmed from that discovery is now seen as applied physics or nanotechnology.

But should chemists be worried by examples such as these? Collaborations are good for science, and chemists bring unique skills to these projects. Does it really matter if the results get called something else? Harvard chemist Stuart Schreiber thinks it does.

"One could say it's a matter of perception or semantics," he says. "But perception and semantics can be important. You might be sending the wrong message to high-school students who are trying to determine which area of science they want to study in college."

Working closely with biologists in Harvard's Institute of Chemistry and Cell Biology, Schreiber's group synthesizes small organic molecules and uses them to study the functions of proteins. The molecules bind to proteins and alter their function - turning off some enzymes, for instance. Known as 'chemical genetics', the technique lets researchers examine the role of individual proteins without mutating the genes that code for them (see Nature 407, 282-284;2000).

"Now do we call that biology or chemistry?" asks Schreiber. "It's both. You're doing hard-core biology and you're doing hard- 


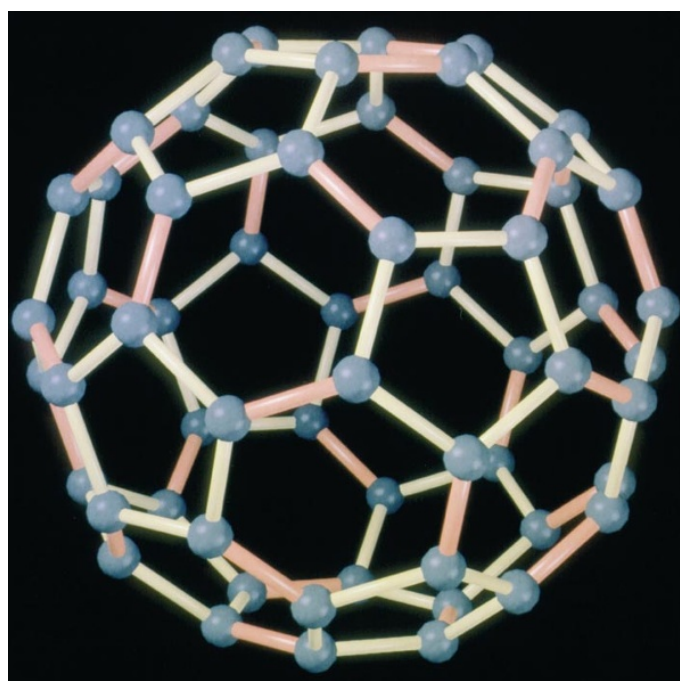

core chemistry. This approach wouldn't exist without the two integrated together.'

So why is chemistry often seen as the silent partner in such collaborations? For Schreiber, it is the difficulty of explaining chemistry to non-experts. "One of the common features is that the research is initiated in a pure chemistry laboratory," says Schreiber. "The chemistry is complex, but the biology can often be described in terms a broader audience would understand."

As an example, he describes how chemists discovered a molecule that inhibits the enzyme HIV protease, which is critical to the AIDS virus's replication. New AIDS treatments followed. "Time magazine's man of the year was David Ho, a clinical researcher in AIDS," says Schreiber. "Did the public feel that this was a breakthrough in chemistry? Ho did a marvellous job, but the focus was so much on the clinical endpoint that it lost sight of where the science came from."

Schreiber and Whitesides say the drive towards interdisciplinary research is coming

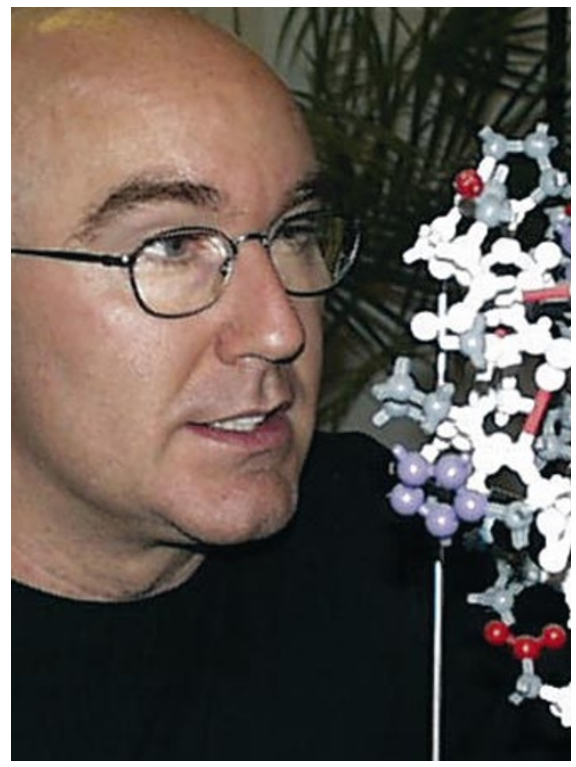

Claim reaction: Stuart Schreiber (left) and George Whitesides want to see chemistry get due credit.

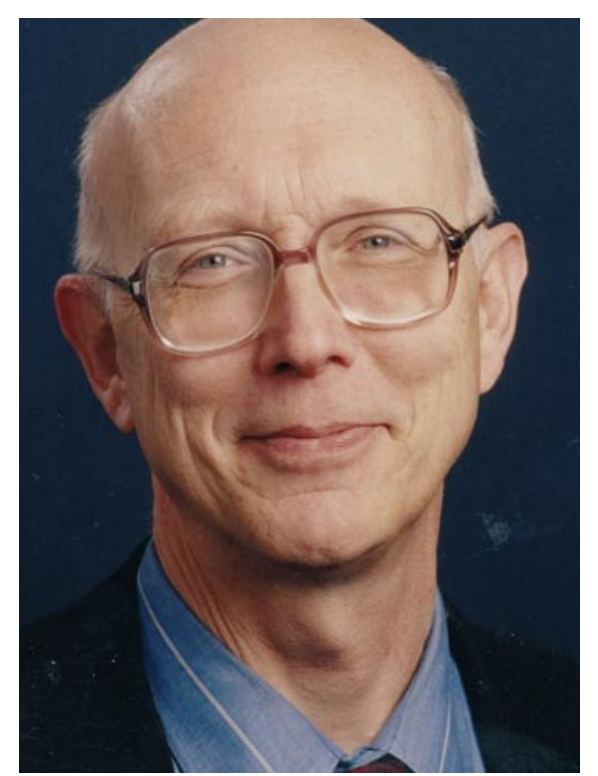

from young researchers keen to stretch their wings. Some senior academic chemists are less enthusiastic, Schreiber says, which is one reason why the discipline has failed to brand its contribution to emerging areas.

Others argue that chemists tend to drop problems when they feel they are moving out of 'pure' chemistry. Michael Ward, a materials chemist at the University of Minnesota, says that chemistry research in universities has been restricted to certain areas. "Chemistry departments have isolated themselves by concentrating on what they perceive as pure science and discarding some research problems," he says. "Things like polymers and surfactants were picked up by chemical engineers and materials scientists, but that's changing now and chemistry is trying to get them back."

Heindirk tom Dieck, secretary-general of the German Chemical Society, adds that chemistry's contribution may be underestimated because it has not produced an eyecatching and expensive 'mega-project' like the human genome or space exploration.

\section{Image problem}

Whatever the cause of chemistry's image problem, the American Chemical Society (ACS) is seen by many as the body best equipped to remedy the situation. With more than 160,000 members, it is the world's biggest scientific organization.

"I think the ACS works tirelessly to create an appropriate and positive image of chemistry," says Schreiber. "On the other hand, I think many of the people involved have not been exposed to chemistry at the interface with modern neighbouring disciplines, and so may tend to understate or under-appreciate that component of our field. What's probably required there is a younger generation of spokespersons and writers who have perhaps a better grasp of what is happening in the highly evolving aspects of chemistry."

The ACS says it is trying to catch up. A recent recruitment drive among younger chemists means that almost half of its members are under 50 for the first time in its 125year history. "We've switched the demographic and the younger members are really helping to drive the society in the direction of being interdisciplinary," says Nancy Ryan Gray, director of the society's membership division. The ACS is also trying to promote chemistry's involvement in emerging disciplines by organizing conferences and publishing new journals on subjects such as proteomics and nanotechnology.

In Britain, the Royal Society of Chemistry (RSC) says it is broadening its membership criteria to allow for the recent growth in the use of chemistry research in biological areas. Researchers who do not have a classical chemistry background but work in 'chemical sciences' will be eligible to join, says Neville Reed, general manager for recruitment, members' services and communication.

Reed says this is part of a move to join up the dots to build up a stronger, more exciting picture of chemistry research. But he believes it is inevitable that some elements will be appropriated by other disciplines. "Chemistry has always been a service subject, it has always provided knowledge and skills that other people want to utilize," he says.

Others argue that not all collaborative projects are good for the subject. "Chemistry is trying to align itself with the excitement of genomics and all the promise that biology brings," says Julius Rebek, a chemist studying self-replicating molecules at The Scripps Research Institute in La Jolla, California. "But the chemistry involved is not leadingedge chemistry; it's pretty much worked out and understood."

Rebek believes the truly pioneering work on the boundary between the two disciplines is the attempt to create synthetic biological systems using chemistry. The big challenges, he says, are tasks like "making a living cell from scratch and making molecules that show primitive signs of life and recreating metabolism". For Rebek, this is pure chemistry. "After all," he says, "you wouldn't be a biologist until you succeeded."

Whatever name is given to such projects, chemists will need to assert themselves if they want the results to be branded as chemistry. Scientific societies can play a role, but when it comes to the crunch, it is down to individual chemists to defend their territory. Perhaps it is time for them to lose a little of their modesty. "What we need is for chemists to talk up their own roles and be proud of what they do," says Reed.

David Adam is a news and features writer for Nature.

American Chemical Society http://www.acs.org Royal Society of Chemistry http://www.rsc.org German Chemical Society http://www.gdch.de 